\title{
КОРДОВА КРОВ ТА ПЕРСПЕКТИВИ ЗАСТОСУВАННЯ ЇІ КОМПОНЕНТІВ В ПРАКТИЦІ ВЕТЕРИНАРНОЇ ХІРУРГІЇ
}

\author{
Краєвський Аполлінарій Йосипович \\ доктор ветеринарних наук, профессор \\ Сумський національний аграрний університет (м. Суми, Україна) \\ ORCID: 0000-0003-2836-8686 \\ kay57@ukr.net
}

Чекан Олександр Миколайович

кандидат ветеринарних наук, доцент

Сумський національний аграрний університет (м. Суми, Україна)

ORCID: 0000-0002-5676-1947

achekanne@gmail.com

Бондаренко Ірина Вікторівна

кандидат ветеринарних наук, доцент

Сумський національний аграрний університет (м. Суми, Україна)

ORCID: 0000-0002-1019-3446

bondarenkolV@gmail.com

Гребеник Наталія Петрівна

кандидат ветеринарних наук, доцент

Сумський національний аграрний університет (м. Суми, Україна)

ORCID: 0000-0002-1254-3374

greb.nata@ukr.net

У статті наведено результати досліджень глікопротеїнів, глікозаміногліканів та церулоплазміну в плазмі крові великої рогатої худоби в динаміці загоєння післякастраційних ран, за використання інтраперитоніальних ін'єктиій сироватки кордової крові. З'ясовано вплив парентерального застосування сироватки кордової крові на показники метаболізму сполучної тканини клінічно здорових тварин та при асептичному запаленні. Кордову кров для отримання сироватки відбирали із судин пуповини під час фрізіологічних родів у корів. Сироватку після центрифугування розливали по 5 мл у стерильні пластикові пробірки і піддавали кріоконсервації у морозильній камері при 18-20 C, яку зберігали до 3-4 тижнів. Визначено рівень церулоплазміну за методикою, що грунтується на окисленні n-френілендиаміну за участю даного металопротеїну.

З'ясовано, що застосування інтраперитоніального введення сироватки кордової крові дозволяє обмежити руйнацію сполучнотканинного матриксу та посилює і модулює гостро фразну відповідь організму на розвиток запальної реакції.

Ключові слова: кордова кров, велика рогата худоба, глікопротеїни.

DOI: https://doi.org/10.32845/bsnau.vet.2021.1.4

Вступ. Кордовою (плацентарною, пуповинною, фетальною) називається кров, що залишається в судинах плаценти і пуповини після народження тварини і відокремлення її від матері. Вона $є$, власне кажучи, частиною крові плоду Barker, Juliet \& Krepski, Timothy, (2002), Armson, B. (2005). Koрдова кров, будучи внутрішнім середовищем зростаючого організму, забезпечує транспорт до різних тканин і органів біологічно активних речовин, що продукуються тканинами фетоплацентарного комплексу. Ці сполуки, різні за своєю природою і джерелом походження, визначають ріст і диференціювання тканин плоду, регулюють його метаболізм.

Імунотолерантність кордової крові зумовлена особливостями фізіологічних і імунологічних характеристик клітин, що містяться в пуповинній крові. На сьогоднішній день кордова кров розглядається як джерело стовбурових клітин i, ймовірно, однією з найбільших переваг кордової крові, у порівнянні з іншими джерелами стовбурових клітин, є її менша імунологічна реактивність, що зумовлює зниження ризику реакції «трансплантат проти хазяїна» Thomson, Blythe \& Robertson (2000); Gluckman, Eliane \& Broxmeyer, HA (1989); Engelfriet, C.P. \& Vanderson, R. (2000).

Аналіз останніх досліджень і публікацій

Однією з особливостей фенотипу лімфоцитів кордо-

вої крові, що характеризує їх як клітини зі специфічною імунореактивністю, є відсутність рецепторів до інтерлейкіну-2. Окрім того, близько 30\% лімфоцитів кордової крові віднесені до так званих «нульових» клітин через відсутність маркерів будь-яких імунокомпетентних клітин на їхній поверхні Uhm, Wan-Sik \& Na (2000).

Вважається, що в пуповинній крові в більшій концентрації, в порівнянні з периферичною кров'ю, присутні CD4+ Tхелпери типу 2, які продукують интерлейкін-2. Даний медіатор, як відомо, виявляє інгібуючий вплив у відношенні до цитотоксичної активності Т-клітин, що також узгоджується зі зниженим цитотоксичним ефектом кордової крові Engelfriet, C.P. \& Vanderson (2000), Harris, David \& Schumacher, M. (1992), Chugunova, L \& Shestakova (1999).

На сьогоднішній день у науковій літературі та клінічній практиці гуманітарної медицини накопичено значну інформацію про позитивний вплив кордової крові, як на різні органи, системи і клітинні культури, так і на організм у цілому. На основі кордової крові створені і використовуються в клінічній практиці такі препарати, які відносять до групи біогенних стимуляторів. Основна відмінність кордової крові як біогенного стимулятора полягає в тому, що вона має у своєму складі збалансований комплекс біологічно активних речовин, що беруть участь в індукції, регресії, зворотного інгібування різних 
ферментів в органах і тканинах реципієнта, завдяки чому можливий вплив на метаболізм не тільки хворого, але і здорового організму без вираженої патології Murohara, T. \& Ikeda, H. \& Duan, J.. (2000), Irina, Petrova. (2013).

Кордова кров та її складові компоненти активно використовуються в сучасних біотехнологічних програмах завдяки своїм унікальним властивостям. Останнє десятиріччя характеризується інтенсивним розвитком нового напряму в медицині - замісної регенеративно-пластичної терапії із використанням плюрипотентних стовбурових клітин кордової крові. Високий клінічний ефект застосування ядро утримуючих клітин і рідких субстратів ембріонального та фетоплацентарного походження зумовлений активним замісним та стимулювальним впливом на функціонально неповноцінні клітини і тканини у окремих органних системах, істотною ініціацією репаративних і метаболічних процесів, імуностимулюючою та імунокорегуючою дією.

Останнім часом у клінічну практику впроваджуються різноманітні методики використання із лікувальною метою не тільки цільної кордової крові, а й її плазми та сироватки.

Сироватка та плазма пуповинної крові містить значну концентрацію комплексу репродуктивних імуномодуляторів, цитокінів, адгезивних компонентів, увесь спектр гормонів, що притаманний організму новонародженої тварини, ростові та антипроліферативні фактори, гемопоетини і адаптогени, опіоїдні пептиди - ендорфіни, енкефраліни, мікроелементи, вітаміни. Однак, незважаючи на підвищений вміст багатьох біо- і імуностимуляторів у кордовій крові, ці речовини знаходяться в збалансованих концентраціях і являють собою біологічно активний комплекс, необхідний для організму, що розвивається та нормалізує обмін речовин при введенні в дорослий організм Rampling, Michael et oll. (1989).

Таким чином, кордова кров, що містить набір специфічних плацентарних білків, гормонів, ростових фракторів, цитокінів, гемопоетичних факторів, інтерлейкінів, опіоїдних пептидів, ферментів і проферментів, вітамінів, мікроелементів та репродуктивних імуномодуляторів, може також знайти широке застосування в практиці ветеринарної хірургії при тих захворюваннях, традиційна комплексна терапія яких передбачає застосування різних біологічних препаратів.

Мета роботи з'ясувати вплив парентерального застосування сироватки кордової крові на показники метаболізму сполучної тканини клінічно здорових тварин та при асептичному запаленні.

Матеріали і методи досліджень. Дослідження проводили на бичках симентальської породи яким виконували кастрацію закритим методом за загальноприйнятою методикою. Надалі тварин було поділено на дві групи: контрольну та дослідну. Тваринам дослідної групи відразу після кастрації інтраперитоніально вводили по 5 мл кріоконсервованої гомологічної сироватки кордової крові. Інтраперитоніальні ін'єкції гомологічної сироватки кордової крові тваринам дослідної групи проводили 1 раз на добу, протягом п'яти діб (всього 5 ін'єкцій).

Кордову кров для отримання сироватки відбирали із судин пуповини під час фізіологічних родів у корів. Сироватку після центрифугування розливали по 5 мл у стерильні пластикові пробірки і піддавали кріоконсервації у морозильній камері при 18-20C, яку зберігали до 3-4 тижнів.

Тваринам контрольної групи інтраперитоніально ін'єктували по 5 мл фізіологічного розчину натрію хлориду в якості плацебо.

Кров для досліджень у тварин обох груп відбирали до кастрації, на 5-ту та 11-ту добу досліджень.

У плазмі крові визначали вміст маркерів метаболізму сполучної тканини - гексоз глікопротеїнів (Г-ГП) та глікозаміногліканів (Г-ГАГ) фрракційним методом за І. В. Невєровим та Н.І. Титаренко (1979) у орциноловій реакції із фракціонуванням етанолом та цетилпіридиній хлористим.

Рівень церулоплазміну визначали за методикою, що грунтується на окисленні n-фенілендиаміну за участю даного металопротеїну.

Отриманий цифровий матеріал оброблено методами варіаційної статистики з використанням параметричного критерію Стьюдента

Результати досліджень Застосування інтраперитоніальних ін'єкцій сироватки кордової крові дозволяє виразно коригувати рівень гексоз сполучених із білком, глікопротеїнів та глікозаміногліканів у плазмі крові кастрованих тварин. Зокрема, на п'яту добу досліджень вміст гексоз сполучених із білком у плазмі крові тварин контрольної групи зріс 3 $1925,0 \pm 77,22 \mathrm{mr} / л$ у інтактних тварин до $2400,0 \pm 141,59$ мг/л $(p<0,01)$, тоді як у дослідній групі вміст гексозовмісних протеїнів проявляв лише тенденцію до зростання і склав $1950,0 \pm 64,62 \mathrm{мг/л}$

Водночас, концентрації глікопротеїнів та глікозаміногліканів у плазмі крові в даний період досліджень мали різноспрямовані зрушення. Так, уміст глікопротеїнів у плазмі крові

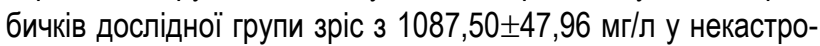
ваних тварин до 1225,0 47,93 мг/л $(p<0,05)$, тоді як у контрольній групі їх рівень навпаки проявляв тенденцію до зниження - 925,0 $\pm 85,49$ мг/л.

Гіперглікопротеїнемія у кастрованих тварин дослідної групи, очевидно пов'язана із здатністю компонентів сироватки кордової крові посилювати синтез прозапальних глікопротеїнів печінкою та коригувати і модулювати фрлогогенні реакції організму в цілому.

Дослідження вмісту глікозаміногліканів у плазмі крові тварин яким застосовували інтраперитоніальні ін'єкції сироватки кордової крові вказують на істотне обмеження та гальмування деградації протеогліканових комплексів матриксу сполучної тканини ділянки кастраційної рани порівняно із тваринами контрольної групи.

Зокрема, концентрація основних маркерів руйнації сполучнотканинного матриксу - глікозаміногліканів у плазмі крові тварин контрольної групи зазнає значного зростання до

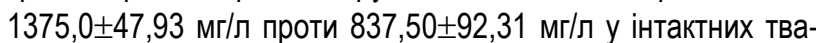
рин, $(p<0,001)$, тоді як при застосуванні інтраперитоніальних ін'єкцій сироватки кордової крові їх рівень навпаки проявляє

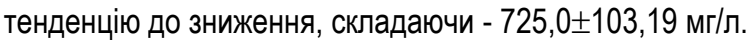

Таким чином, застосування сироватки кордової крові дозволяє обмежити руйнацію сполучнотканинного матриксу та посилює гостро фазну відповідь організму на розвиток запальної реакції. Окрім цього, інтраперитоніальні ін'єкції сироватки кордової крові сприяють збереженню в умовах максимального прояву запальної реакції у кастраційних ранах оптимального індексу співвідношення між рівнем глікозаміногліканів та глікопротеїнів у плазмі крові оперованих тварин - 0,6 проти 0,8 у інтактних тварин та майже 1,5 у контрольній групі.

Наприкінці досліджень (одинадцята доба) рівень глікопротеїнів у плазмі крові тварин дослідної та контрольної груп наблизився до показника некастрованих тварин, скла-

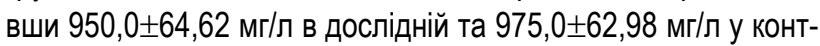
рольній групі, відповідно. 
Водночас, уміст глікозаміногліканів у плазмі крові тварин контрольної групи зріс порівняно із показником некастрованих до $1550,0 \pm 28,90 \mathrm{mг} / л,(p<0,001)$ а у дослідній до

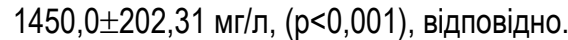

Зростання рівня глікозаміногліканів у період гранулювання та епітелізації кастраційних ран, поряд із затуханням запальної реакції пов'язаний на нашу думку із активацією синтезу і формуванням протеогліканів та колагенових волокон.

При запаленні відбувається швидкий синтез колагену та білково-вуглеводних комплексів сполучної тканини, однак, одночасно із цим прискорюється і деградація колагену та протеогліканових комплексів, тобто ці компоненти у запаленій тканині $€$ незрілим і обмін їх посилюється.

В той же час, при застосуванні сироватки кордової крові рівень глікозаміногліканів в даний період досліджень проявляє тенденцію до зниження відносно значень тварин контрольної групи, що є свідченням формування більш повноцінного колагену та протеогліканового матриксу грануляційної тканини посткастраційних ран.

Поряд із корекцією вмісту в плазмі крові маркерів метаболізму сполучної тканини на тлі застосування сироватки кордової крові, спостерігалася й позитивна клінічна динаміка перебігу ранового процесу, що характеризувалася формуванням помірного запального набряку тканин рани та прискоренням росту грануляційної тканини, і в цілому дозволяє скоротити терміни загоєння кастраційних ран на 5-7 діб порівняно із тваринами контрольної групи.

Дослідження рівня гостро фазного мідьумісного білку - церулоплазміну у плазмі крові кастрованих тварин на п'яту добу спостережень після виконання інтраперитоніальних ін'єкцій сироватки кордової крові свідчать про істотне зрос-

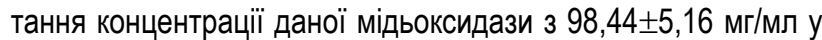
інтактних тварин, до 131,25 $\pm 7,15$ мг/мл, (р<0,002), тоді як у контрольній групі це зростання було менш виразним і склало $115,94 \pm 4,19 \mathrm{мг/мл,}(\mathrm{p}<0,02)$.

На одинадцяту добу досліджень вміст церулоплазміну у плазмі крові кастрованих тварин зазнавав зниження наближаючись до показника інтактних тварин склавши $109,38 \pm 5,65$ мг/мл у дослідній та 100,63 $\pm 5,65$ мг/мл у контрольній групі, відповідно.

Таким чином, застосування інтраперитоніальних ін'єкцій сироватки кордової крові активує синтез церулоплазміну у печінці та експресію даного реактанта гострої фази запальної реакції у плазмі крові, чим попереджається дестабілізація клітинних мембран та процеси ліпопероксидації.

3413 зразків крові 66 (16\%) були SAA +. SAA + зразки мали підвищений рівень загального білка, $\operatorname{lgM}, \lg \mathrm{G}$ і нейтрофіли та зниження лімфоцитів, еозинофілів та зниження рівня альбуміну порівняно зі збірними зразками SAA.

Загальна поширеність серед зразків крові SAA + становила 16\%; проте, тварини на прив'язному утриманні, мали набагато вищу поширеність SAA + $(26 \%)$.

Види та частота запальних та незапальних ознак не спостерігається у день відбору проб.

Аналізуючи наведені дані, можна оцінити наскільки точні отримані дані спостережень за коровами, коли мова йде про SAA як остаточного маркера запалення. Будь-яка корова з запальними ознаками вважалася такою ж, як і корова лише з однією запальною ознакою, тобто всі корови були позитивні або негативні щодо запальних ознак. Конгломерат для кожного класу ферми з виявленням запалення, виміряним щодо SAA як стандарту запалення було виявлено в обох господарСтвах.

Вісник Сумського національного аграрного університету
"Позитивний\%" - це поширеність SAA для типу ферми. Чутливість $є$ мірою позитивних спостережень щодо запалення щодо всіх позитивних (позитивні за SAA).

Хибно позитивні - це кількість "неправильних" спостережень (виявлене запалення), коли згідно за SAA не було запалення. Кількість хибнопозитивних результатів становила 17 iз 347 (5\%).

Під час операції неконтрольована або дифузна кровотеча може призвести до множинних клінічних та економічних негативних наслідків для тварини.

Несприятливі ефректи включають:

- Потреба у переливанні крові. Якщо не вдається впоратися належним чином, хірургічна кровотеча збільшує тривалість хірургічної процедури, а також може збільшити потребу пацієнта у переливанні крові.

Серйозні інфекційні та неінфекційні побічні явища, пов'язані з переливанням алогенної крові та продуктів крові. Хоча інфрекції, що передаються через переливання крові, зменшились, поінформованість та звітність неінфекційних ускладнень переливання (наприклад, імунологічні реакції, помилки переливання) збільшені та неінфекційні ускладнення в даний час $€$ найбільш поширеною та більш смертоносною групою захворювань, пов'язаних із переливанням крові.

Неправильне переливання компонентів крові, що призводить до гемолітичного переливання реакції та гостра травма легенів, пов'язана з переливанням крові (TRALI), залишаються основними джерелами захворюваності та смертність.

- Зниження температури серцевини. Велика крововтрата під час травматичних операцій або тривалих хірургічних процедур може спричинити зниження серцевої температури пацієнта, і втрата температури має прямий вплив на згортання крові.

Коли температура тіла наближається до $34^{\circ} \mathrm{C}\left(93,2^{\circ}\right.$ F), тромбоцити починають втрачати здатність агрегуватися; це відоме як гіпотермічна коагулопатія.

- Тромбоцитопенія. Це поширений гемостатичний дефріцит, який може розвинутися під час операції, оскільки масивної крововтрати, що вимагає заміни або після введення гепарину (тобто індукованого гепарином тромбоцитопенія).

Наслідки тромбоцитопенії включають крововиливи або тромботичні події.

- Гіповолемічний шок. Це відбувається в результаті виснаження судинного об'єму від крововиливу під час операції і може зменшити серцевий викид, оскільки серце не може повністю заповнитись. Після того, як пацієнт програє 10\% його загального обсягу крові, серцевий викид і центральний тиск починають падати. Як результат, організм компенсує, викликаючи периферичну вазоконстрикцію для поліпшення серцевого поштовху та легеневого газообміну, і відбувається діафорез. Ці зміни можуть призвести до компенсованого шоку, і організм здатний компенсувати втрату об'єму. Однак, якщо втрата крові не припиняється і об'єм замінюється, з часом компенсаторні механізми виходять з ладу.

Значний обсяг досліджень в останні роки був спрямований на профрілактику операційних ускладнень. Первинна проффілактика в основному націлена на передбаченні фактори ризику навколишнього середовища.

Альтернативною профілактичною стратегією $є$ модифікація регуляторних компонентів імунної системи, зокрема, регуляторних Т-клітин Foxp3 + (Tregs). Існують нові докази на моделях тварин і людей, які свідчать про те, що втрата нор- 
мальної імунологічної самотолерантності при хірургічній патології, що є вирішальним етапом його патогенезу, може бути пов'язана з недостатністю Tregs.

Пуповинна кров багата на Tregs, які пригнічують функцію при антигенній стимуляції, а також є джерелом гемопоетичних та плюрипотентних стовбурових клітин. Таким чином, існує суттєве наукове обґрунтування потенціалу пуповинної крові для запобігання або затримки початку хірургічних патологій. Дослідження CoRD свідчить, що може вливання аутологічної пуповинної крові високим ризиком хірургічної патології, що мають сироваткові антитіла до множинних $\beta$-клітинних антигенів. Паралельно під час дослідження буде вивчатися імунологічний ефект інфузії пуповинної крові. Це вперше буде проведено таке дослідження хірургічної патології у корів, хоча під час дослідження використовували аутологічну пуповинну кров після початку хірургічних ускладнень. При дослідженні I фази ранового процесу, у якому взяли участь 24 корови (середній вік, 5,1 року), інфузій аутологічної пуповинної крові було пов'язано з тимчасовим збільшенням загальної кількості та наївних трег на 6 та 9 місяців відповідно. Побічних явищ не спостерігалося. Тим не менше, втручання не зберегло функцію $\beta$-клітин, оскільки рівень С-пептиду знижувався після інфузії. Однак час після встановлення діагнозу, часто спостерігається швидка втрата маси $\beta$-клітин, і це зниження могло статися до введення інфузії.

Оскільки клінічне застосування алотрансплантатів UCB набуває значущості, механістичний зв'язок між цими продуктами та регенерацією тканин повинен бути повністю вивчений. Дослідження таких алотрансплантатів зосереджувались головним чином на вмісті стовбурових клітин через їх походження з тканин народження. Однак дослідження на доклінічних моделях дають зрозуміти, що фактично терапевтичний вплив, а не стовбурові клітини, мають реальний терапевтичний вплив in vivo Chugunova, L et oll. (1999). Раніше ми показали, що аллотрансплантати, отримані з UCB, можуть індукувати проліферацію, міграцію та ангіогенез завдяки цитокінам, присутнім в UCB. Знання, отримані в результаті постійних досліджень таких алотрансплантатів, спонукали до спроб виявити нові параметри контролю якості, які можуть бути корисними для визначення критеріїв вивільнення придатності. У міру того, як регулятивні настанови продовжуватимуть розвиватися, параметри, що стосуються регенеративних механізмів, також, ймовірно, будуть включені в розробку системи контролю якості. Це перше у своєму роді дослідження з метою вибору набору ознак контролю якості, які можуть бути використані для визначення клінічної придатності алотрансплантатів, отриманих з UCB.

Ми перерахували клітинний компонент на додаток до кількісної оцінки цитокінів та ідентифікації нових сигнальних білків, щоб мати повне уявлення про алотрансплантат. Загальна кількість клітин та відсоток життєздатності клітин відповідали серед досліджуваних зразків. Хоча життєздатність клітин та їх метаболічну активність неможливо співвіднести 3 ефективністю продукту, це свідчить про рівномірність виробничого процесу. Ми виявили значний відсоток життєздатних клітин в UCBr; однак дуже низька фракція забарвлювалась позитивно на маркери стовбурових клітин згідно з рекомендаціями Міжнародного товариства клітинної терапії Miyahara, Hiroaki \& Okazaki, et. oll. (2010). Ці дані не виключають можливості присутності стовбурових клітин у клітинах аллотрансплантата пуповинної крові. Виділення стовбурових клітин 3 UCB було успішно здійснено раніше із застосуванням специфічних підходів до культури тканин Phadnis, et. oll. (2006);
Samareh Salavati Pour, et. oll. (2020). Цікаво побачити, чи дозволяють клітини UCBr, культивовані в таких умовах in vitro протягом тривалого періоду часу, покращувати імунозабарвлення маркерів поверхні стовбурових клітин. Однак це виходить за рамки цього дослідження оцінки якості і може бути центром майбутніх досліджень. Хоча ми не передбачаємо залежності UCBr від популяції життєздатних клітин як функції його клінічної вигоди, це демонструє, що методи кріоконсервації без ДМСО є щадними, але ефективними для підтримки цих ніжних клітин. Двостороння реакція змішаних лімфоцитів показала, що клітини, що знаходяться в UCBr, не проліферують, і біологічні ефекти не залежать від метаболічної функції цих клітин. Протеомічне профрілювання зразків виявило кілька білків, які можуть впливати на загоєння ран, метаболізм АФК тощо. Наскільки нам відомо, це перший звіт про ідентифікацію глобальних білків, пов'язаних 3 алотрансплантатами UCB. Випадкове відбір зразків для протеомічного профілювання як частина звичайного контролю якості може виявити можливі відхилення у виробничому процесі. Близько 31 цитокіни, які відіграють пряму або непряму роль у регенерації тканин, були визначені кількісно з великої когорти донорів і визнані послідовними. Хоча мінливість донорів неминуча, суворі критерії включення-виключення, засновані на кількісному виявленні критичних трофічних факторів, можуть обмежити варіабельність продукту та бути частиною параметра контролю якості.

Для визначення біообтяження донорної пуповинної крові та асептичної природи $\mathrm{UCBr}$ дотримувались рекомендацій cGTP. Менше 10\% зданих зразків крові було відхилено через результати серології, що підкреслювали важливість ефективного скринінгу донорів з чітко визначеними критеріями включення-виключення донорів. Обробка в постійно відстежуваному, контрольованому середовищі може різко зменшити мікробне забруднення. Протягом 24 місяців 99,98\% продуктів переробки були асептичними. Алотрансплантати, які регулюються як НСТ / Ps, не повинні тестуватися на рівень ендотоксину або імуногенність. Але на основі аналізу повідомленого використання цих алотрансплантатів ці тести можуть мати клінічну значимість. Рівні ендотоксину в усіх випробовуваних продуктах UCBr становили <2,5 €C / мл, використовуючи найсуворіші критерії допустимої межі ендотоксину для фармацевтичних препаратів. Тестування рівня ендотоксину на кожній партії донорів може бути включено як звичайний захід контролю якості для забезпечення клінічної безпеки у певних випадках. UCBr був неімуногенним, як визначено MLR, навпаки, він пригнічував проліферацію алогенних PBMC. Це частково можна віднести до протизапальних цитокінів, таких як IL-6, -10 та -13. Концентрація іншого протизапального цитокіну IL-1RA становила приблизно 30000 пг / мл, найвища серед усіх перевірених цитокінів. Клінічні випробування щодо пригнічення активності IL-1 з IL-1RA прийшли до висновку, що це безпечний та ефективний спосіб полегшення GvHD, який не реагував на звичайне лікування [33]. Надалі було б цікаво вивчити вплив UCBr на пом'якшення GvHD за допомогою $\mathrm{p}$

Незважаючи на очевидну необхідність у добре розроблених дослідженнях для вивчення конкретних терапевтичних застосувань пуповинної крові, існують важливі відмінності у способах збирання, зберігання та забезпечення доступу пуповинної крові у державних та приватних банків, що може вплинути на потенційні дослідження. Державні банки зберігають здані одиниці пуповинної крові для алогенного викорис- 
тання, приблизно 3000 одиниць зберігаються щороку в Австралії (близько 1\% живонароджених). Швидкість інкасації в державних банках залежить від наявності

Висновки та перспективи подальших досліджень.

1. Застосування компонентів кордової крові при хірургічній патології у тварин є новим та перспективним напрямком патогенетичної та корегуючої запальну реакцію терапії.

2. Інтраперитоніальні введення сироватки кордової крові дозволяють обмежити руйнацію сполучнотканинного матриксу та посилюють і модулюють гостро фазну відповідь організму на розвиток запальної реакції.

В перспективі, подальші дослідження з даної проблеми слід продовжити у напрямку визначення ефективності застосування компонентів кордової крові за акушерсько-гінекологічної та ортопедичної патології у продуктивних тварин.

\section{Список використаної літератури:}

1. Barker, Juliet \& Krepski, Timothy \& Defor, Todd \& Davies, Stella \& Wagner, John \& Weisdorf, Daniel. (2002). Searching for unrelated donor hematopoietic stem cells: Availability and speed of umbilical cord blood versus bone marrow. Biology of blood and marrow transplantation : journal of the American Society for Blood and Marrow Transplantation. 8. 257-60. 10.1053/bbmt.2002.v8.pm12064362.

2. Armson, B.. (2005). Umbilical Cord Blood Banking: Implications for Perinatal Care Providers. Journal of obstetrics and gynaecology Canada : JOGC = Journal d'obstétrique et gynécologie du Canada : JOGC. 27. 263-90. 10.1016/S1701-2163(16)305205.

3. Thomson, Blythe \& Robertson, Kent \& Gowan, Darla \& Broxmeyer, Hal \& Emanuel, David \& Kotylo, Patricia \& Brahmi, Zacharie \& Smith, Franklin. (2000). Analysis of engraftment, graft-versus-host disease, and immune recovery following unrelated donor cord blood transplantation. Blood. 96. 2703-2711. 10.1182/blood.V96.8.2703.

4. Gluckman, Eliane \& Broxmeyer, HA \& Auerbach, Arleen \& Friedman, Henry \& Douglas, Gordon \& Devergie, Agnès \& Esperou, Hélène \& Thierry, Dominique \& Socie, Gerard \& Lehn, Pierre. (1989). Hematopoietic Reconstitution in a Patient with Fanconi's Anemia by Means of Umbilical-Cord Blood from an HLA-Identical Sibling. The New England journal of medicine. 321. 1174-8. 10.1056/NEJM198910263211707.

5. Engelfriet, C.P. \& Vanderson, R. \& Wagner, J.E. \& Sobocinski, K.A.. (2000). Graft versus Host Disease in Children Who Have Received a Cord Blood or Bone Marrow Transplant from HLA-Identical Siblings. Vox Sanguinis. 79. 10.1046/j.14230410.2000.79402652.x.

6. Uhm, Wan-Sik \& Na, K \& Song, G-W \& Jung, S-S \& Lee, T \& Park, Moon Hyang \& Yoo, D-H. (2003). Cytokine balance in kidney tissue from lupus nephritis patients. Rheumatology (Oxford, England). 42. 935-8. 10.1093/rheumatology/keg255.

7. Harris, David \& Schumacher, M \& Locascio, J \& Besencon, F \& Olson, G \& DeLuca, D \& Shenker, L \& Bard, Judith \& Boyse, E. (1992). Phenotypic and functional immaturity of human umbilical cord blood T lymphocytes. Proceedings of the National Academy of Sciences of the United States of America. 89. 10006-10. 10.1073/pnas.89.21.10006.

8. Chugunova, L \& Shestakova, Marina \& Shamkhalova, M. (1999). Primenenie glikozaminoglikanov v lechenii diabeticheskoy nefropatii. Diabetes mellitus. 34. 10.14341/2072-0351-5562.

9. Murohara, T. \& Ikeda, H. \& Duan, J.. (2000). Transplanted cord blood-derived endothelial precursor cells augment postnatal neovascularization.. J Clin Invest. 105.

10. Irina, Petrova. (2013). Biologicheskie-svoystva-novyh-proizvodnyh-uratsila.

11. Rampling, Michael \& Whittingstall, P \& Martin, G \& Bignall, Simon \& Rivers, R \& Lissauer, Tom \& Bailey, P. (1989). A Comparison of the Rheologic Properties of Neonatal and Adult Blood. Pediatric research. 25. 457-60. 10.1203/00006450-19890500000006.

12. Kordek, Agnieszka \& Giedrys-Kalemba, Stefania \& Pawlus, Beata \& Podraza, Wojciech \& Czajka, Ryszard. (2003). Umbilical Cord Blood Serum Procalcitonin Concentration in the Diagnosis of Early Neonatal Infection. Journal of perinatology : official journal of the California Perinatal Association. 23. 148-53. 10.1038/sj.jp.7210885.

13. Miyahara, Hiroaki \& Okazaki, N \& Nagakura, Tomokazu \& Korematsu, S \& Izumi, T. (2010). Elevated umbilical cord serum TARC/CCL17 levels predict the development of atopic dermatitis in infancy. Clinical and experimental allergy : journal of the British Society for Allergy and Clinical Immunology. 41. 186-91. 10.1111/j.1365-2222.2010.03634.x.

14. Phadnis, Smruti \& Joglekar, Mugdha \& Venkateshan, Vijayalakshmi \& Ghaskadbi, Surendra \& Hardikar, Anandwardhan \& Bhonde, Ramesh. (2006). Human Umbilical Cord Blood Serum Promotes Growth, Proliferation as well as Differentiation of Human Bone Marrow-derived Progenitor Cells. In vitro cellular \& developmental biology. Animal. 42. 283-6. 10.1290/0512087.1.

15. Samareh Salavati Pour, Maryam \& Vahidi, Reza \& Lashkari, Mahla \& Derakhshani, Ali \& Ameri, Zahra \& Farsinejad, Alireza. (2020). Cord blood serum harvesting by hydroxyethyl starch: a fetal bovine serum alternative in expansion of umbilical cordderived mesenchymal stem cells. Cytotechnology. 72. 10.1007/s10616-020-00404-9.

Kraevsky Apollinaryi., Doctor of Vet. Science, Sumy National Agrarian University (Sumy, Ukraine)

Musienko Yurii., PhD of Vet. Science, Sumy National Agrarian University (Sumy, Ukraine)

Chekan Olexandr, PhD of Vet. Science, Sumy National Agrarian University (Sumy, Ukraine)

Bondarenko Iryna, PhD of Vet. Science, Sumy National Agrarian University (Sumy, Ukraine)

Grebenik Natakyia. PhD of Vet. Science, Sumy National Agrarian University (Sumy, Ukraine)

Cord blood and the prospects for the use of its components in the practice of veterinary surgery.

The article presents the results of studies of glycoproteins, glycosaminoglycans and ceruloplasmin in the blood plasma of cattle in the dynamics of healing of post-castration wounds using intraperitoneal injections of cord blood serum.

The aim of the study was to determine the effect of parenteral administration of cord blood serum on the metabolism of connective tissue in clinically healthy animals and in aseptic inflammation. The studies were conducted on gobies of Simmental breed 
which were castrated by the closed method according to the generally accepted method. Subsequently, the animals were divided into two groups: control and experimental. Immediately after castration, animals of the experimental group were intraperitoneally injected with $5 \mathrm{ml}$ of cryopreserved homologous cord blood serum. Intraperitoneal injections of homologous cord blood serum to animals of the experimental group were performed once a day for five days (5 injections in total).

Cord blood for serum was taken from the umbilical cord vessels during physiological delivery in cows. After centrifugation, the serum was poured into $5 \mathrm{ml}$ sterile plastic tubes and cryopreserved in a freezer at 18-20 ${ }^{\circ} \mathrm{C}$, which was stored for 3-4 weeks.

Animals of the control group were intraperitoneally injected with $5 \mathrm{ml}$ of physiological sodium chloride solution as a placebo.

Blood for studies in animals of both groups was taken before castration, on the 5th and 11th day of research.

In the blood plasma, the content of markers of connective tissue metabolism was determined - hexoses of glycoproteins (GGP) and glycosaminoglycans (G-GAG) by the fractional method according to I.V. Neverov and N.I. Titarenko (1979) in an orcinol reaction with fractionation with ethanol and cetylpyridinium chloride.

The level of ceruloplasmin was determined by the method based on the oxidation of $n$-phenylenediamine with the participation of this metalloprotein.

The resulting digital material was processed by the methods of variation statistics using the parametric student criterion.

Intraperitoneal injections of cord blood serum help maintain the optimal ratio between the level of glycosaminoglycans and glycoproteins in the blood plasma of operated animals under conditions of the maximum manifestation of the inflammatory reaction in castration wounds

It has been established that the use of intraperitoneal administration of cord blood serum allows limiting the destruction of the connective tissue matrix and enhances and modulates the acute phase response of the body to the development of the inflammatory response.

Key words: cord blood, cattle, glycoproteins 